\title{
The Notion of "Court" under the Succession Regulation
}

\begin{abstract}
The article concerns the notion of "court" in the Succession Regulation. This notion is used in the Brussels I and Brussels Ia Regulations, where it does not necessarily have the same scope. The author attempts to interpret the concept in the light of the recitals to the Succession Regulation (in particular Recital 20) and of the case law of the Court of Justice. The very general description of the concept contained in Article 3(2) of the Regulation might potentially embrace other authorities and legal professionals, where they exercise judicial functions by way of delegation of power from the court. In the author's view, the European Court, especially in Oberle and WB v Notariusz Przemystawa Bac correctly navigated its way through the Succession Regulation and ruled in a way which is both coherent as regards the operation of the Regulation and consistent with the intentions of the legislator. The above judgments are analysed also with regard to Poland's omission to notify notaries as "courts" under Article 79 of the Succession Regulation. The European Court found that the criteria for determining whether an authority or a legal professional, in particular a notary public, constitutes a "court" are determined by Article 3(2) and not by Article 79. Consequently, Poland's omission to notify was not conclusive, but was in any event correct in substance. The author expresses the opinion that the judgment is accurate on this point.
\end{abstract}

Keywords: EU Succession Regulation - the notion of "court" - authentic instruments judicial body - competent authority

a) Legal Advisor, European Commission. 


\section{Introduction}

Within the scheme of the Succession Regulation ${ }^{1}$, the notion of "court" assumes considerable importance. Courts are bound by the jurisdiction rules of the Regulation ${ }^{2}$, whereas other authorities, such as notaries, are not, unless they are exercising judicial functions ${ }^{3}$. Court decisions circulate under Chapter IV of the Regulation, ${ }^{4}$, whereas documents drawn up by other competent authorities, in particular notaries, do not; however, such documents may circulate as authentic instruments if the necessary conditions are met $^{5}$.

At the same time, the Succession Regulation does not provide an exhaustive definition of "court". Instead, it gives a very general description, which potentially embraces other authorities and legal professionals, ${ }^{6}$ and requires the Member States to make a notification to the Commission of all such authorities and legal professionals that it designates as "courts"7. The Commission then publishes the list (and any subsequent amendments thereto) of such authorities in the Official Journal and through the European Judicial Network ${ }^{8}$.

In these circumstances, it is unsurprising that the European Court has been called upon to give guidance on how to interpret this concept. In this writer's view, the Court has, by and large, correctly navigated its way through the murky shallows of the Regulation and ruled in a way

${ }^{1}$ Regulation 650/2012 on jurisdiction, applicable law, recognition and enforcement of decisions and acceptance and enforcement of authentic instruments in matters of succession and on the creation of a European Certificate of Succession, [2012] OJ L 201/107.

${ }^{2}$ Article 4 of the Regulation provides as follows: "The courts of the Member State in which the deceased had his habitual residence at the time of death shall have jurisdiction to rule on the succession as a whole."

${ }^{3}$ Recital 22 provides in pertinent part that: "When notaries exercise judicial functions, they are bound by the rules of jurisdiction ...When notaries do not exercise judicial functions, they are not bound by the rules of jurisdiction...".

${ }^{4}$ Chapter IV is entitled "Recognition, Enforceability and Enforcement of Decisions". Article 39 provides that "a decision given in a Member State shall be recognised in the other Member States". "Decision" is defined in Article 3(1)(g) as "any decision in a matter of succession given by a court of a member State".

${ }^{5}$ Recital 22 states that: "when notaries exercise judicial functions ... the decision they give (sic) should circulate in accordance with the provisions on recognition, enforceability, and enforcement of decisions". On the other hand: "when notaries do not exercise judicial functions ... the authentic instruments they issue (sic) should circulate in accordance with the provisions on authentic instruments".

${ }^{6}$ Article 3(2), infra.

${ }^{7}$ Article 3(2), second sub-paragraph, read in conjunction with Article 79.

8 Article 79. 
which is both coherent as regards the operation of the Regulation and consistent with the intentions of the legislator.

\section{Definition of "court"}

Article 3(2) of the Regulation defines a "court" as "any judicial authority and all other authorities and legal professionals with competence in matters of succession which exercise judicial functions or act pursuant to a delegation of power by a judicial authority or act under the control of a judicial authority, provided that such other authorities and legal professionals offer guarantees with regard to impartiality and the right of all parties to be heard and provided that their decisions under the law of the Member States in which they operate may be made the subject of an appeal or to review by a judicial authority and have a similar force and effect as a decision of a judicial authority on the same matter".

In order to make some sense of this definition, one needs to consult the recitals in the preamble to the Succession Regulation, in particular Recital 20. Strictly speaking, the purpose of recitals is simply to explain the purpose behind the provisions of a given piece of EU legislation and the language of recitals ("should") reflects this idea. Nevertheless, in practice, the proper interpretation of many provisions of EU law requires reading them in conjunction with the recitals: this phenomenon is very conspicuous in the instruments adopted in the civil law field (where recitals often take the place of an Explanatory Report) and is especially the case with the Succession Regulation, in which some of the recitals, in reality, assume normative value.

Recital 20 is somewhat ambiguous. On the one hand, it states first that the term court should "be given a broad meaning", so as to embrace not only "courts in the true sense", but also in particular "notaries or registry offices" where they exercise judicial functions like courts and "notaries or legal professionals" where they exercise judicial functions by way of delegation of power by a court. On the other hand, the final sentence of the recital adds a note of caution by specifying that the term should not cover "notaries in most Member States where, as is usually the case, they are not exercising judicial functions".

Clearly, the legislature was preoccupied by the role of notaries in matters of succession in the very different systems of the Member States. Even in those Member States in which notaries have a general compe- 
tence in non-contentious matters, it does not necessarily follow that they are thereby acting as courts. The legislature was therefore concerned to give some guidance as to where to draw the line. It has however been left up to the Court of Justice to put flesh on the bones.

The Court has already had to grapple with the interpretation of the notion of "court" within the meaning of the Brussels $\mathrm{I}^{9}$ and European Enforcement Order Regulations..$^{10}$ Although the Court's reasoning is not necessarily wholly transposable to the different context of the Succession Regulation, the judgments nevertheless repay careful study.

In the Pula Parking ${ }^{11}$ judgment ${ }^{12}$, the Court held that notaries were not courts for the purpose of the Brussels Ia Regulation unless they were deemed to be so by an explicit provision ${ }^{13}$. In this respect, it focused first on the essential difference between judicial and notarial functions. ${ }^{14}$ Second, it laid stress on the importance of mutual trust in the context of both regulations, in particular on the aspect that courts in the Member States must be able to have confidence that judgments handed down in other Member States "had been delivered in court proceedings offering guarantees of independence and impartiality and in compliance with the principle of audi alteram partem" 15 . Reading between the lines, the Court seemed to imply that, even if the notary carried out judicial functions, he could not be characterised as a court since he was not part of the judicial system ${ }^{16}$. However, the Court was careful to stress that, ultimately,

${ }^{9}$ Regulation 1215/2012 on jurisdiction and the recognition and enforcement of judgments in civil and commercial matters [2012] OJ L 351/1.

${ }^{10}$ Regulation 805/2004 creating a European Enforcement Order for uncontested claims [2004] OJ L 143/15.

11 CJEU, 9.3.2017, C-551/15 Pula Parking ECLI:EU:C:2017:193.

12 The Court came to the same conclusion regarding the European Enforcement Regulation in CJEU, 9.3.2017, C-484/15 Zulfikaparsic, ECLI:EU:C:2017:199. Although the cases were not formally joined, they were decided by the same Chamber and pleaded on the same day, although, curiously enough, a different Advocate General was assigned to each case, infra. Judgment was delivered on the same day in both cases.

${ }_{13}$ The concept of court is not defined in either Regulation. However, Article 3(a) of the Brussels Ia Regulation provides that, in Hungary, in summary proceedings concerning orders to pay, notaries are deemed to be courts. Despite the fact that the role of Croatian notaries in the context of such summary proceedings was very similar to that of Hungarian notaries, the Court considered (correctly it is submitted) that this was a deeming provision, not simply a clarification of a borderline case. Consequently, a contrario, unless such a notary was specifically mentioned, he fell outside the scope of the definition.

${ }^{14}$ C-551/15 Pula Parking, para. 47, citing earlier case law.

${ }_{15}$ C-551/15 Pula Parking, para. 54.

${ }_{16}$ See on this point also the Opinion of A-G Bobek in C-551/15 Pula Parking who clearly articulates the distinction between being part of the judicial architecture and the exercising of judicial functions. In essence, he promulgated a test focussing primar- 
it was for the legislature to determine what constituted a court for the purposes of a given regulation and pointed out that the Succession Regulation is less rigid than the Brussels Ia Regulation, in that it clearly does contemplate that a notary may in certain circumstances be a court.

The Court thus wisely avoided prejudging the definition of court for the purposes of the Succession Regulation. It therefore remained an open question as to what extent the reasoning in these two judgments was transposable to that Regulation.

Since the judgments in Pula Parking and Zulfikaparsic, the Court has given judgments in two cases concerning the notion of "court" for the purposes of the Succession Regulation: the judgments provide valuable clarification of the notion of courts under the Succession Regulation and are both, in the author's view, demonstrably correct.

In the first of the discussed cases, Oberle ${ }^{17}$, the European Court was faced with the situation of a testator who at the time of his death had been habitually resident in France. The deceased owned property in both France and Germany. The relevant French court had issued a national certificate of succession stating that the two sons of the deceased each inherited half of the estate. One of the brothers then applied to the competent court in Germany for a certificate of succession to the same effect, but limited to the part of the estate situated in Germany. The first instance court in Germany declined jurisdiction on the basis that, by virtue of Article 4 of the Regulation, only a French court would have jurisdiction to issue such a certificate. On appeal, the referring court

ily on whether an authority forms part of the normal judicial structure of a Member State (para. 90 of the Opinion). If so, it is prima facie to be treated as a court, subject to a possible correction taking as its inspiration the Court's case law on what is a "court or tribunal" within the meaning of Article 267 TFEU. Thus, in order to be treated as a court, the body must also offer sufficient guarantees in terms of independence, impartiality, inter partes contradictory procedure and overall respect for the rights of the defence (para. 105). Cf. the Opinion of A-G Bot in C-484/15 Zulfikarpasic. Although that Opinion contains some common features with the Opinion of A-G Bobek, it falls into the error of assuming that, because the notary is under an obligation to check certain facts of his own motion, this is tantamount to protecting rights of the defence, despite the obvious lack of any contradictory procedure and the fact that the notary, despite being clothed with certain state functions is, like any lawyer, a professional acting for a client. Since under Croatian law the notary issued an order for payment on the basis only of a bill rather than any independently verifiable evidence, the analysis of Advocate General Bot on this point is demonstrably incorrect. It was clearly (and correctly) rejected by the Court's statement that "the examination by notaries in Croatia of an application for a writ of execution on such a basis is not conducted on an inter partes basis".

${ }_{17}$ CJEU, 21.6.2018, C-20/17 Oberle, ECLI:EU:C:2018:485; noted L. Per reau-Saus sine: Quelle place pour les certificats nationaux dans le règlement Successions internationales, no 650/2012?. "Revue critique de droit international privé", 2018, p. 850. 
asked whether Article 4 applied to the issuing of national certificates of succession.

Whilst there was no doubt that the competent authority was, from a structural point of view, a court, the issue was whether it was bound by the rules of jurisdiction of the Regulation, in particular Article 4, which provides that the courts of the last habitual residence of the deceased "have jurisdiction to rule on the succession as a whole". The debate thus focused on whether the expression "to rule" applied only to decisions adopted by national courts exercising their judicial functions or whether it also extended to the issuing of national certificated of succession, not having the force of res judicata, at the end of a non-contentious procedure ${ }^{18}$.

The Court decided that "to rule" embraced any decision of a court, even the issuing of a national certificate in non-contentious proceedings. It invoked a number of arguments in support of this conclusion.

First, the Court referred to Article 13 of the Succession Regulation. This provision stipulates that, in addition to the court having jurisdiction over the succession, a court of the habitual residence of any person entitled under the lex successionis to make any declaration concerning the acceptance or waiver of the succession, of a legacy or of a reserved share, or a declaration relating to the limitation of liabilities under the succession was also to have jurisdiction to receive such a declaration. The very existence of this provision implies that, without it, only the court having jurisdiction over the succession as a whole would be competent to receive such a declaration. It was thus a clear indication that the jurisdiction referred to in Article 4 also embraced decisions in noncontentious matters ${ }^{19}$.

Second, the Court referred to Recital 59, which states that, in the light of the objective of mutual recognition of decisions in matters of succession, "irrespective of whether such decisions were given in contentious or non-contentious proceedings", the Regulation should lay down rules inter alia on jurisdiction similar to those in other instruments in the field of private international law ${ }^{20}$.

${ }^{18}$ In Germany the "herrschende Meinung in der Literatur" defended the theory that the jurisdiction provisions of the Regulation did not apply to national certificates of succession. See, for example, J. Weber, C. Schall: Internationale Zuständigkeit für die Erteilung deutscher Erbscheine: (k)eine Frage der europäischen Erbrechtsverordnung? "Neue Juristische Wochenschrift" 2016, 3564; F. Wall: Richtet sich die internationale Zuständigkeit zur Erbscheinserteilung künftig ausschließlich nach Artt. 4 ff EU-Erb-VO? "Zeitschrift für die Steuer- und Erbrechtspraxis" 2015, 9. Aliter; V. Grau: Deutscher Erbschein und Europäische Erbrechtsverordnung. In Festschrift für Eberhard Schilken. Hrsg. C. Meller-Hannich, L. Haertlein, H.F. Gaul, E. Becker-Eberhard. München 2015.

${ }^{19}$ C-20/17 Oberle, paras. 41, 42.

${ }^{20}$ C-20/17 Oberle, para. 43. 
This would have been enough to dispose of the matter but the Court also devotes 16 paragraphs to dealing with two further points. First, it analyses the interplay between the normal rules of jurisdiction and the special regime relating to the issuing of a European Certificate of Succession and, second, the objective of ensuring as far as possible that the court having jurisdiction applies its own law as applicable law.

As regards the first two main points mentioned above, the Oberle judgment should be read alongside the Opinion of A-G Szpunar who analyses the issues raised not only in more detail but also in a more orderly fashion. He pointed out in particular that, under the regime of the Brussels Ia Regulation, a judgment must emanate from a judicial body "deciding on its own authority on the issues between the parties". However, he considered that Recital 59 of the preamble to the Succession Regulation was clear in indicating that, in determining the definition of a decision, it is irrelevant whether it was given in contentious or noncontentious proceedings.

The message of the Oberle judgment is thus unequivocal: when issuing a national certificate of succession even in non-contentious proceedings a court is still a court. Consequently, it is bound by the rules of jurisdiction set out in Chapter II (Articles 4 and the following) of the Regulation.

A number of other conclusions follow by necessary implication.

The German government had argued that national certificates of succession did not fall within the scope of the Regulation and thus jurisdiction to issue such a certificate was governed by national law ${ }^{21}$. It claimed that its interpretation of the Regulation on this point was to the benefit of the heirs and beneficiaries since, if it was correct, it would enable them to obtain a national certificate in Germany, rather than needing, in France, to ask for a European Certificate of Succession, which might be more expensive to obtain and more difficult to have accepted in other Member States.

However, the premise on which this argument is based is demonstrably false. It overlooks the fact that, mutatis mutandis, the French certificate of succession drawn up by the French court was also to be regarded as a decision ${ }^{22}$. It could therefore circulate under Chapter IV of the Regulation and its effects could be "recognised" (loosely speaking) in Germany. It would therefore be unnecessary for the joint heirs in that

${ }^{21}$ Opinion of Advocate General Szpunar, para. 311.

${ }^{22}$ Normally, under French law, such a certificate would have been drawn up by a notary. However, (albeit the point is not made explicit in the judgment or the national file), a court was competent by virtue of the special rules applying in the Moselle, Bas-Rhin and Haut-Rhin départements (L. Perreau-Saussine: Quelle place...). 
case to acquire either a European Certificate of Succession in France or a national certificate of succession in Germany, even in respect of immovable property forming part of the estate and located in Germany. ${ }^{23}$

The second important judgment in this respect is WB v Notariusz Przemysława Bac. ${ }^{24}$ This case is in some respects the reverse of Oberle. It concerns the issue of whether a Polish notary, who draws up a certificate of succession at the unanimous request of all the parties to the procedure, constitutes a court; if the question were to be answered in the affirmative this would mean that the certificate would constitute a decision and could circulate under Chapter IV of the Regulation.

However, the Court answered the question in the negative ${ }^{25}$. While acknowledging that the concept of "court" should be given a broad interpretation in the context of the Succession Regulation ${ }^{26}$ the Court of Justice nevertheless reiterated that the exercise of a judicial function presupposes that the relevant person has the competence to rule on his own motion on points of dispute between the parties. This is not the case where the powers of the professional concerned are entirely dependent on the will of the parties ${ }^{27}$. Since, under Polish law, the notaries have power to draw up the certificate only at the unanimous request of the parties, it followed that they are not thereby exercising a judicial function, despite being under an obligation to verify that the requirements for issuing the certificate had been complied with.

Reading the two judgments together, the results may at first sight seem inconsistent; the notary in $W B$ is not treated as a court despite the fact that he is exercising what is to all intents and purposes the same function as the Amtsgericht Schöneberg in Oberle. However, the explanation is simple: the Amtsgericht Schöneberg is a court "in the true

${ }^{23}$ CJEU, 12.10.2017, C-218/16 Kubicka, EU:C:2017:965. The judgment in Kubicka was delivered after the Oberle case had been pleaded.

${ }^{24}$ CJEU, 23.5.2019, C-658/17 WB ECLI:EU:C:2019:444.

${ }_{25}$ The Court instead held that a deed of certification of succession drawn up by a notary may be certified as an authentic instrument and hence circulate under Chapter $\mathrm{V}$ of the Succession Regulation, provided that it satisfied the conditions set out in the Regulation. Since the authenticity of the document must relate not only to the signature but also to the content, if the authenticity relates only to the signature by the parties, the document will not satisfy the criteria. In this respect, the Court stressed that, under Polish law, the notary is required to carry out checks, which may lead him to refuse to draw up the deed. Hence, the authenticity of the instrument relates both to signature and content. By stressing this point, the Court clearly envisages that, where the duty of the notary is limited to recording the statement of the parties and does not extend to verifying the facts, the deed will not qualify as an authentic instrument. This, however, is a question for another day.

${ }^{26}$ C-658/17 WB, para. 53.

${ }^{27}$ Ibidem, para. 55 . 
sense of the word", ${ }^{28}$ in that it forms part of the judicial system, whereas a notary does not; he is a self-employed professional. There is therefore no paradox in determining that "a court is always a court" whereas a notary, who is not structurally speaking a court, is not a court unless he is exercising a judicial function and then only if he offers the guarantees of impartiality, independence and respect for the rights of the defence that a true court would.

\section{The legal significance of notifications under Article $\mathbf{7 9}$}

By virtue of Article 3(2) of the Regulation, read in conjunction with Article 79, Member States must notify to the European Commission the "other authorities and legal professionals" that constitute courts within the meaning of the definition set out in Article 3(2). The Commission must then publish the list and any subsequent amendments in the Official Journal and through the European Judicial Network in civil and commercial matters.

Of the 25 Member States bound by the Regulation, 16 have not made any notification under Article 79 (or have explicitly stated that only courts are competent, which amounts to the same thing). Two have notified executors. Of the remaining seven, the Czech Republic, Spain and Portugal have made very precise notifications regarding notaries, specifying that they are not to be treated as courts except when they exercise certain specific statutory functions. The remaining four notifications are problematic. Hungary and Croatia have notified notaries, claiming that in succession matters they always act as courts, which simply cannot be right, whereas Greece and Latvia have purported to notify notaries, but have done so in a very ambiguous way ${ }^{29}$.

By virtue of Article 79, the European Commission has no formal power to refuse a notification made by a Member State or to require a Mem-

${ }^{28}$ Cf. the wording of Recital 21.

${ }^{29}$ For example, the notification by Greece states that notaries are competent in matters of succession and adds that they are vested with authority to draw up authentic acts. On the face of it, this does not seem to, purport to be a notification that notaries act as courts. The remainder of the notification is dedicated to a eulogy of notaries ("lawyers with high academic training" "play an active and effective role in preventive justice, safeguarding the rights of all those appearing before them").

The notification by Latvia contains the same ambiguity, albeit without the fulsome praise for notaries. 
ber State to make such a notification. This raises the question of the legal value of a notification or absence thereof when the Member State has not properly assessed the issue according to the principles laid down by the Court of Justice.

The question was raised by the national court in WB, supra. Since, as it transpired, Poland was quite correct in not having notified notaries, the question did not, strictly speaking, call for a reply; nevertheless, the Court addressed it.

The Court pointed out that the criteria for determining whether an authority or legal professional, in particular a notary, is a court are determined by Article 3(2) and not by Article 79. It would inter alia undermine the objective of the Succession Regulation if a Member State could determine unilaterally which bodies are or are not courts. This conclusion is corroborated by Recital 21. Consequently, Poland's omission to notify notaries under Article 79 was not conclusive.

The conclusion is undoubtedly correct. However, certain aspects of the Court's reasoning on the effect of an incorrect notification or failure to notify are puzzling.

In the first place, the Court states that a notification under Article 79 creates a "presumption" that the authority declared is indeed a court ${ }^{30}$ whereas a failure to notify an authority has "merely indicative value" ${ }^{1}$.

If the Court thereby intended to state that an incorrect (positive) notification of a particular authority has some kind of higher probative status than an erroneous failure to notify an authority, then it is submitted that the Court fell into error. The statements seem to imply that, whereas an incorrect positive notification at least has the merit that the Member State has made an assessment, and thus addressed its mind to the question, a failure to notify implies a lack of any assessment and thus a lack of care. If this is what the Court meant, it is wrong: a failure to notify an authority under Article 79 is in reality a tacit notification that that authority does not fulfil the conditions for being treated as a court. There is therefore no reason to treat an incorrect failure to notify an authority as a court as being worthy of less respect than an incorrect positive notification.

In the second place, the Court purports to give instructions to national courts that have doubts as to whether a notification has been correctly made. In para. 45 of the judgment, the Court states that "a national court hearing a dispute concerning whether an authority ... qualifies as a "court"... or which has doubts as to the accuracy of the declarations

${ }^{30}$ C-658/17 WB, para. 43.

${ }^{31}$ Ibidem, para. 48. 
made by a Member State, may query whether the conditions listed in [Article 3(2) are satisfied] and, if so, submit ... a request for a preliminary ruling" (emphasis added). The expression "if so" in the English text of the judgment seems to imply that if a national court wishes to call into question a notification made by a Member State, it may do so only if it first makes a reference for a preliminary ruling. However, it is apparent that "if so" in the English version of the judgment is in fact a mistranslation of the French expression "le cas échéant", which is better translated by "if necessary" or "as the case may be" 32 . In other words, the Court is not requiring a hypothetical national court to make a reference for a preliminary ruling as a condition of departing from the classification made by the competent Member State, but simply reminding it of the possibility that exists under Article 267 TFEU.

This would mean that if a national court is asked to classify an authority differently from the relevant Member State, it may do so on its own responsibility, with the possibility of making a reference if it considers that it needs to do so. Only a court from which there is no appeal would be obliged to make a reference. That said, it is clearly preferable from the point of view of legal certainty for a lower court to make a reference in order to have the matter conclusively determined.

\section{Consequences of a body being characterised a court}

As mentioned above, if an authority is a court within the meaning of Article 3(2), it follows, on the one hand, that it is bound by the rules of international jurisdiction set out in Articles 4 and the following ${ }^{33}$. On the other hand, any decision of a court, whether in contentious or noncontentious proceedings, will be recognised in the other Member States, and may be enforced there, under Chapter IV of the Regulation.

${ }^{32}$ Cf. CJEU, 30.5.2018, C-517/16 Czerwiński EU:C:2018:350 on the cognate issue of the value of a declaration made by a Member State under the Social Security Regulation, cited by the Court at para. 43 of WB. There the Court states that a notification made is not definitive and that the classification may therefore be made by the national court referring "if necessary, a question for a preliminary ruling". In that judgment, the French expression "le cas échéant" is translated correctly.

${ }^{33}$ However, if a court wrongly assumes jurisdiction, this would not prevent a decision from circulating under the Regulation, since this is not listed in Article 40 as a ground of non-recognition. 
If an authority is not a court, it is not bound by the rules of jurisdiction. However, any deed or certificate that the authority draws up will not circulate under Chapter IV but may be "accepted" and as the case may be enforced under the provisions of Chapter V, provided that the document is an authentic instrument, in particular as regards the authenticity of its content.

The significance of the distinction between "acceptance" of an authentic instrument and "recognition" of a decision handed down by a court in non-contentious proceedings will no doubt need to be worked out in due course.

\section{References}

Grau V.: Deutscher Erbschein und Europäische Erbrechtsverordnung, in Festschrift für Eberhard Schilken. Hrsg. C. Meller-Hannich, L. Haertlein; H.F. Gaul, E. Becker-Eberhard. München 2015.

Perreau-Saussine L.: Quelle place pour les certificats nationaux dans le règlement Successions internationales, no 650/2012? "Revue critique de droit international privé", 2018.

Wall F.: Richtet sich die internationale Zuständigkeit zur Erbscheinserteilung künftig ausschließlich nach Artt. 4 ff EU-Erb-VO? "Zeitschrift für die Steuer- und Erbrechtspraxis" 2015.

Weber J., Schall C.: Internationale Zuständigkeit für die Erteilung deutscher Erbscheine: (k)eine Frage der europäischen Erbrechtsverordnung? "Neue Juristische Wochenschrift” 2016. 